\section{B A Institute of \\ YK Business Administration \\ 六下 \\ Karachi \\ Leadership and Ideas for Tomorrow}

Business Review

Volume 5 Issue 2 July-December 2010

$7-1-2010$

\title{
Determinants of outsourcing decision in the manufacturing industry In Bangladesh
}

Aminul Islam

University Malaysia Perlis, Malaysia

Farid Ahammad Sobhani

University Sains Malaysia, Malaysia

Follow this and additional works at: https://ir.iba.edu.pk/businessreview

Part of the Business Commons

(c) (1)

This work is licensed under a Creative Commons Attribution 4.0 International License.

\section{Recommended Citation}

Islam, A., \& Sobhani, F. A. (2010). Determinants of outsourcing decision in the manufacturing industry In Bangladesh. Business Review, 5(2), 127-148. Retrieved from https://doi.org/10.54784/1990-6587.1248

This article is brought to you by iRepository for open access under the Creative Commons Attribution 4.0 License and is available at https://ir.iba.edu.pk/businessreview/vol5/iss2/8. For more information, please contact irepository@iba.edu.pk. 


\title{
ARTICLE
}

\section{DETERMINANTS OF OUTSOURCING DECISION IN THE MANUFACTURING INDUSTRY in BANGLADESH}

MD. AMINUL ISLAM

University Malaysia Perlis, Malaysia

FARID AHAMMAD SOBHANI

University Sains Malaysia, Malaysia

\begin{abstract}
The purpose of this study was to identify and understand the factors influencing outsourcing decision in the manufacturing industry in Bangladesh. Existing literature revealed that many manufacturing industry were faced with challenges in the competitive environment to be competitive in the market and produce products at the minimum cost as possible yet meeting customer specification without affecting the quality and delivery schedule. Thus, outsourcing could be an alternative to solve most of the problems faced by the manufacturing industry in Bangladesh. This stirred these researchers to identify and understand the possible factors influencing the manufacturing industry in outsourcing decision whether these factors could really influence the management to opt for outsourcing and help in solving the problems. The theoretical framework was developed to hypothesize four components namely reduce operating cost, improve company focus, access to world class capability and unavailability of internal resources in relation to influence outsourcing decision in the manufacturing industry. The proposed study utilized the exploratory approach, whereby the survey method was used. The data was collected through questionnaires in various manufacturing industry in Bangladesh. The findings were analyzed using a statistical software package (SPSS), and the main tools that were used were Cronbach's Alpha, descriptive and linear regression analysis. The findings revealed that the factors or components identified for the study had significant effect on outsourcing decision except reduce operating cost. This study provided evidence that these factors would influence outsourcing decision in the manufacturing industry in Bangladesh. The recommendations are also offered more in-depth guidelines for maximizing the benefits of outsourcing.
\end{abstract}

Keywords: Outsourcing, manufacturing concerns, critical success factors, Bangladesh

\section{INTRODUCTION}

Outsourcing decisions are those strategic decisions that change the operations strategy of an organization both in manufacturing and services. The most important step in any outsourcing decision is to clearly define the scope of the operations that are being 
considered for outsourcing (Cook, Mary, F. and Gildner, Scoot B. 2008). Human resource professionals throughout the world are being asked to do more or less, to enhance productivity while controlling costs and to find out new ways to increase profitability. (Uddin, Gazi, M. 2005).

In the competitive environment of manufacturing concerns and evolving technology era, to enhance efficiency and productivity, cost remains a challenge to all manufacturing industry to compete with rivals in providing the best total lower cost to end customers and to secure the market share in order to add value to the shareholders. Having to invest heavily in capital investment such as machineries, buildings and land to expand space in supporting the production operation is a burden to most companies if the return of investment is not profitably. Most of the companies that were struggling to expand the capacity to support the ramp up demand at times were disappointed when there was a drastic downturn of demand cut. As a result, the sudden downturn would affect the resources and investment that were put into supporting the end customers' demand. Pool of human resources and machineries that consumed production space and being idled would increase the overhead and fixed cost, thus affecting the companies badly in their financial statements. In addition, training and development to up skill internal resource skills set in terms of running the operation effectively, bringing up technical content expert, specialist ability to perform research and development to add value, effective management and maintaining the operation would require significant investment in human resources (David Mackey and Kaye Thorne, 2003). Thus, most of the companies started to explore opportunities to reduce cost and to improve profit margin in order to maintain competitive edge in the market. One of the identified opportunities was to outsource non-core business functions to external service providers at a lower operating cost.

Outsourcing is not a new notion. For decades, jobs have been migrated from other part of the countries namely American and European countries as well as other overseas countries to global service providers primarily India, China, Singapore and Malaysia due to lower operating cost. According to Cynthia A. Kroll (2004), a regional economist from University of California Berkeley, the recent wave of outsourcing affected a different mix of jobs, at different wage levels. It was not confined only to a small set of industries but cut across all industrial sectors in new geographic area rapidly (Cynthia A. Kroll, 2004). William P. DiMartini (2005), Senior Vice President at SunGard Availability Services said businesses in all industry segments found that limited internal resources would make outsourcing an attractive, cost-effective and prudent option that would allow them to focus on their core competencies (AccountingWEB.com, 2005).

\section{8}


Demand for outsourcing is a result of demand for organizational products by the target audience. On the basis of organizational estimate of total turnover, practicing managers can attempt to establish the nature and type of outsourcing required to that esteemed goal (Uddin, Gazi M. 2005). Outsourcing advantages to name a few include lower operating cost, improve competitiveness, low in capital investment, shift resources to focus on core functions, generate demand for new growth and market segment, access to world class capability, sharing risks and make capital funds available for core business investment.

Bangladesh, a developing country, largely an agrarian economy with around 24 million acres of cultivation land employing about 14.5 million cultivators. Manufacturing industries have grown around Dhaka and Chittagong based on agriculture input of jute, cotton, chemical, cement, and gas based industries. Industrial production growth has averaged more than $6 \%$ over the last 5 years. The export sector has been the engine of industrial growth, with ready-made garments leading the way, having grown at an average of $30 \%$ over the last 5 years. Primary products constitute less than 10 percent of the country`s exports; the bulk of exports are manufactured/processed products, ready-made garments and knit wears in particular. (www.euroitx.com)

There are many manufacturing concerns in Bangladesh that are looking into outsourcing opportunity to reduce cost and to overcome the internal limitations and achieve lower cost of operation. The country is now moving towards industry based economy from the agro-based one. Hence, this study was an attempt to access determinants influencing the outsourcing decision and to research the manufacturing concern in Bangladesh on how well the factors would influence the manufacturing industry in Bangladesh to outsource certain function of their business areas to external service providers. The study also aimed at finding out the influencing factors that influenced the companies in outsourcing decision and helped the companies to overcome the internal limitation barriers.

\section{PRIOR LITERATURE}

\section{Outsourcing Review}

In the early 1980 s, 'outsourcing' typically referred to the situation while organizations expanded their purchases of manufactured physical inputs, like car companies that purchased window cranks and seat fabrics from outside the firm rather than making them inside. Nowadays, outsourcing took on a different meaning. Presently it refers to a specific segment of the growing international trade in senices. This segment consists of arm's-length, or what Bhagvati (1984) called 'long-distance,' purchase of services abroad, principally, but not necessarily, via electronic mediums such as the 
telephone, fax and the Internet. Outsourcing can happen both though transactions by firms, like phone call centers staffed in Bangalore to sen7e customers in New York and $\mathrm{X}$-rays transmitted digitally from Boston to be read in Bombay, or with direct consumption purchases by individuals, like when someone hires an offshore firm to provide plans for redesigning or redecorating a living room (Bhagwati, J. et al. 2004)

In an era of rapid technological change and short product life cycles, companies were trying to reduce cost and maintain quality at the same time which implied that companies would need to specialize in what they did best and de-emphasize management attention from business processes that did not directly impact the business. Outsourcing was a means to partner with service providers so they could handle specific business processes - better, faster and at a lower operating cost (V. Krishna Polineni, 2001). It was defined as the transferring one or more internal functions of an organization to an external service providers. According to the analyst Dean Davison, the outsourcing was growing about 20 percent to 25 percent per annum (Dean Davison, 2006). Outsourcing has become an alternative, which all major corporations must consider in order to remain competitive. It helped to increase efficiency, improve service quality, accountability, values, decreased headcounts and cash infusion and gain access to world class capability and sharing risk (The Outsourcing Institute, 2006)

One of the primary advantages of outsourcing arises quickly from the reduction of overheads. This might give rise to an immediate, and possibly one-off, advantage in terms of the avoidance of future or recurrent capital outlay, and the savings in office space and equipment provisions if these could be released during the outsourcing decision. There was clearly a staff cost reduction possible here, and this could be the predominant element in directly-attributable, ongoing cost savings. The spin-off from this might benefit the business support services department where the outsourcing was partial, and could be especially useful where the capital cost was high and recurrent, particularly if there was uncertainty about the future costs of maintaining effective and competitive business support. It was an investment risk transfer, in other words. Where outsourcing is total, the benefit was accrued directly by the core business - it translated to a capital injection to the customer's business. This was one of the major driving reasons of the outsourcing of IT provision in the early 1990s - generally agreed as having been led in 1989 by Kodak, which outsourced all of its IT operations to IBM (Jonathan ReuvidÊandÊJohn Hinks, 2001). This could also confer a great deal of flexibility on the company. For a centralized organization which was providing a range of its support services from its own personnel and offices, the move to outsourcing could allow a downsizing of the property commitments. Consider the impact on the organizational infrastructure requirements of a change to outsourcing IT provision, payroll and credit processing, pensions, catering, recruitment, training, Human Resource Management (HRM), cleaning, security, lettings, software development, estates and building 
management. It could also confer direct scope for downsizing or increased options for organizational re-structuring through property and HRM flexibility.

The transferal of a non-core service provision to a variable cost would allow economies of scale to be passed on from the supplier, and also would mean that incremental changes in the process capacity of the customer (upwards or downwards) could be covered at proportional rather than quantum cost changes. Where scope to vary the scale of the contracted supply was agreed, this has allowed the business organization to make maximum use of its marginal capital for core process change rather than noncore process support change. This could allow decreased time to market for new products or processes, and also increased scope for changes. Outsourcing solutions can provide an excellent chance to get the company service provision out of a rut and, if properly managed, to stimulate new solutions to problems from the mixing of different approaches.

A noticeable feature of the global economy is the enhancing international products. Robert Feenstra (1998) describes the remarkable international specialization in the manufacturing products. For example, the raw materials of manufacturing products like Barbie dolls (plastic and hair) are obtained from Taiwan and Japan. Assembly used to be done in those countries as well as to lower cost locations like Philippines, Indonesia, Malaysia, and China. The growth in international specialization can also be observed in aggregate statistics. William Zeile and Gorden Hanson et al (2003) document the importance of trade within multinational firms. David Hummels et al. (2003) show that trade in intermediate inputs has grown faster than trade in finished products. While the globalization of production may yield important productivity benefits, there is a widespread view that it has also adversely affected low skilled workers. There are frequent media reports on how low-skilled labours in the first world countries are hurt when manufacturing jobs are relocated in the US and in many other countries have picked up on this theme to push for greater restrictions on trade with developing countries. Yet, despite its prominence in the public debate, there is little systematic evidence of the extent to which low-skilled workers are harmed by outsourcing to poor countries (Hsieh, Chang T. and Woo, Keong T., 2005).

Outsourcing has existed in the USA for over 30 years particularly the business process outsourcing (BPO). The Bank of America, Best Buy, Delta Airlines, Goodyear, IBM, the Marriott, Motorola, PepsiCo, Procter \& Gamble, and Sun Microsystems are all outsourcing HR functions. US federal and state governments also spend billions each year doing so also. HR functions are not just being outsourced, they are being sent offshore. The US companies have off-shored their manufacturing and their R\&D facilities in their semiconductors, computing, chemicals and pharmaceuticals to the UK, Germany, France, Ireland and other developed countries (). 
In view of developing countries, outsourcing takes place more recently to India and China. In 2003, 1.5 million service jobs were outsourced to the developing world and the number was projected to surge to 4.1 million by year 2008 (El'millian Chew Saint Fey, 2005). According to the Offshore Location Attractiveness Index published by AT Kearny (2004), Malaysia, an emerging South East Asian nation, was the third most desirable location for offshore outsourcing in the world, after India and china. In Malaysia, the demand for outsourcing was not only from global multi-national companies but also from local companies. The demand for outsourcing was driven by the fact that companies could access a more reliable infrastructure that could ensure smooth core business operations at lower costs and with greater flexibility. Outsourcing also encouraged the pooling of resources for a more efficient use of resources to reap the benefits that could be derived from economies of scale.

Bangladesh has potential in outsourcing in its competitive business environment with a relatively low cost structure as well as support from the government and nongovernment organizations. In view of outsourcing demand, Bangladesh could be very well take advantage of this fact by attracting quality outsourcing operators to the country. The availability of quality resources especially in the private sector to support the outsourcing demand, this could be made available to support off-shore and local outsourcers. HR outsourcing organizations in Bangladesh are in stage of booming up and most of the organizations have realized that they should play more attention to networking activities. Uddin, Gazi M. (2005) describes the challenges and prospects of effective HR outsourcing for managerial activities in the corporate world of Bangladesh. The study reveals that networking activities play a strong role in HR outsourcing and duration of outsourcing is temporary. The study mainly focused on HR outsourcing, not on the factors influencing outsourcing decisions.

Literature review shows that several comprehensive studies have been conducted in the world regarding outsourcing specifically HR outsourcing, general time management, managerial jobs, and managerial behavior and so on. But no significant study in the light of this research has been found. It is not claimed by the researchers that all of the literature regarding outsourcing decisions have been reviewed, but normally available literatures have been reviewed and none of them were found specifically written in the horizon of particular issue. In this research paper, the researchers would explore the extensiveness of factors influencing the outsourcing decision in the manufacturing industry of Bangladesh through the survey of the sample companies.

\section{Factors Influencing Outsourcing Decision}

Outsourcing has a long-established feature of cost effective business practice. The necessity to review what to remain in house and what would be contracted to 
external vendors has been dramatically increased over time by two factors: the thrust for competitive advantage in the global economy and successful business focus on its core competencies (Sandra Ward, 2004). The attraction offered by significant wage differentials has therefore stimulated moves of in-house production facilities to lower wage economies, using both outsourcing and off-shoring approaches. From initial IT and software development, financial services, business process supports, the outsourcing approach was beginning to be seen in research, engineering design or development, production function and many others. The locations for off-shoring were growing especially in the Asia region such as India, China, Singapore, Malaysia and Bangladesh. Although cost savings was still a very important consideration factor (Sounders et al., 1997), companies were outsourcing for other reasons as well not only just due to lower operating cost.

According to the Outsourcing Institute executive survey (2006), the top ten reasons why companies would outsource are as follows: Reduce and control operating cost, Improve company focus, Gain access to world class capability, Free resources for other purposes, Resources are not available internally, Accelerate re-engineering benefits, Non-core function that is too complex to manage, Make capital funds available, Share risks, and Cash Infusion

There were also reasons companies outsource due to lack of technology capability, strategic advantage to the companies, better service quality vendor and sound contract, lack of internal capacity in meeting production ramp demand and also possible limited space for expansion.

\section{RESEARCH MODEL}

\section{Theoretical Framework}

The literature review has indicated top ten factors according to the Outsourcing Institute that have major influence on outsourcing decision. These factors were primarily applied to offshore outsourcer and locally. Despite Bangladesh is ranked the third most desirable location for offshore outsourcing in the world, after India and china, Bangladesh could be a strategic hub for outsourcing too (El'millian Chew, 2005). The aim of the study was to perform a research in the Bangladesh manufacturing industries to validate the truth of the factors that indicated by the Outsourcing Institute that influenced the outsourcing decision by the management. The researcher would also assess on the effectiveness of the relationship between the factors as independent variables and the outsourcing decision as dependant variable. The researcher selected partial of the top ten factors as listed in the literature review for the research and the remaining factors would be a good starting point for research in this area in the future. In this framework, 
the dependent variable being studied would be the outsourcing decision. The four factors influencing outsourcing decision as independent variables being studied would be reduce operating cost, improve company focus, gain access to world class capability and unavailability of internal resources. The research framework is shown as Figure 3.1 below.

Independent Variables

\begin{tabular}{|l|}
\hline Reduce Operating Cost \\
Capital investment \\
Overhead and fixed cost \\
Space \\
\hline mprove Company Focus \\
Focus on new product development and explore \\
new market segment. \\
\hline Access toWorld Class Capability \\
Availability of specialist \\
Latest and high efficiency technology \\
Established tools and support infrastructure \\
Unavailability of Internal Resources \\
Limited production capacity and Space. \\
Lack of technical content experts and Suppor \\
Infrastructure
\end{tabular}

Dependent Variable

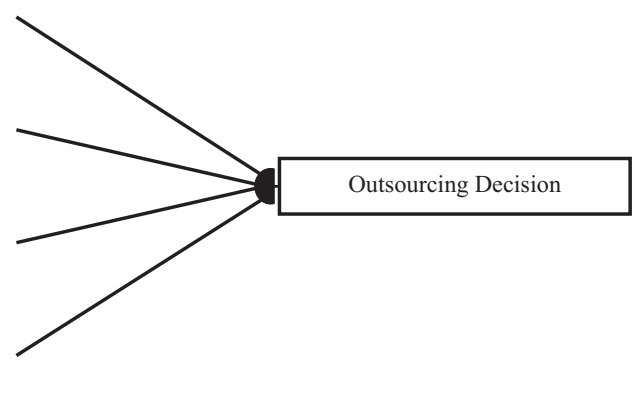

Figure 1: Schematic Diagrame of the Research Framework

\section{Statements of Hypothesis}

As shown in figure 1 above, based on the theoretical framework, the statements of hypotheses were developed in the following sections based on the four selected independent variables which were reduce operating cost, improve company focus, access to world class capability and unavailability of internal resources.

\section{Reduce in Operating Cost}

This variable was a measure of the customers on how they considered outsourcing would help in reducing the operating cost in their companies. The three areas being measured would be the capital investment, overhead and fixed cost and space.

Capital investment was a measure of the extent on how outsourcing would help and has positive impact in reducing capital investment such equipments, building and land for instance to reduce operating cost. By outsourcing non-core operation function areas, inevitably, some portion of capital investment could be saved and the investment fund could be diverted to core business investment to bring in more revenues to the companies. The fund could also be used on researching and generating new market segment development. 
Outsourcing has positive impact in reducing capital investment that helps to reduce operating cost.

Overhead and fixed cost was a measure of the extent on how outsourcing would help and has positive impact to reduce operating cost for example human resources, fixed assets and utility cost. In most companies, outsourcing would help to reduce number of headcounts or employees whereby the core employees were shifted to focus on core functions. Thus, outsourcing would also reduce fixed asset quantity such as machinery and reduced the concern on depreciation value. Utility cost could also be reduced with less consumption.

Outsourcing has positive impact in reducing overhead and fixed cost that helps to reduce operating cost

Space was a measure of the extent on how outsourcing would help to reduce space consumption, flexibility for core business use, capacity expansion to generate new revenues and cash infusion to reduce operating cost.

Outsourcing has positive impact in reducing space that helps to reduce operating cost

Therefore, this study was proposed with three components of hypotheses related to reduce in operating cost as highlighted above. As per the literature review, researchers have found evidence that outsourcing led to reduce in operating cost. In the Outsourcing Institute survey (2006), it was found that reducing operating cost was one of the top ten factors that influenced companies to outsource some of their business functions.

\section{Improve Company Focus}

This following variable was a measure of the customers on how they considered outsourcing would help to improve company focus in their companies. There would be one area being measured on diverting resource to support core function that was to focus on new product development and explore new market.

As per the literature review, the benefits of outsourcing article cited that by outsourcing, resources could be diverted in value add activities that increased shareholder values. By shifting the resource to focus on core business and new product development, this would significantly produce a tremendous impact to the companies in exploring new market segment and reap new customers to boost the revenues profitably. 
Outsourcing has positive impact in focusing on new product development and explore new market segment to improve company focus.

\section{Gain Access to World Class Capability}

In this section, this variable was a measure of the impact of outsourcing in gaining the access to world class capability. Customers would be measured on how outsourcing would help with the access of supplier's best in class specialist, latest and high efficiency technology that could produce higher yield rate and would they gain the access of better established tools and support infrastructure at the supplier site.

Based on the literature review, according to the Outsourcing Institute survey (2006), one of the top ten factors or reasons companies outsource was to gain access to the world class capability that was not available in-house.

Most of the suppliers that were specialized in their core service provider function have the best in class specialist that has sound technical and hands-on experiences engineers or specialists compared to outsourcer that were not specialized in the noncore business area. Suppliers would be able to provide the content expert resource that would support the requirement effectively and efficiently as deemed specialist.

\section{Outsourcing provides the access to world-class capability with supplier's best in class specialist}

Service provider would usually have the best in class of the latest and high efficiency technology considering that the providers were specific in the service business function area. This would give them the added advantage to compete with their rivals in winning the business from outsourcer. Having latest technology equipments and high efficiency would inevitable produce better quality and yield outputs and at a higher capacity rate.

\section{Outsourcing provides the access to world class capability with supplier's latest and high efficiency technology}

As elaborated in the above, service providers would be deemed specialist and have the latest and high efficiency technology would also necessary to be equipped with established supporting tools and infrastructure. Service providers has well established training and development plan in place to support the customers' need and should have best in class of information technology systems and tools infrastructure to support the specialized type of business transaction. 
Outsourcing provides the access to world-class capability with supplier's established tools and support infrastructure

These three components of hypotheses above described that outsourcing would provide the access to the world-class capability in relation to the researcher's survey. These hypotheses would be assessed and analyzed the truth of the relationship to outsourcing decision in chapter four.

\section{Unavailability of Internal Resources}

In manufacturing operation industry, majority of the companies outsource due to the unavailability of internal resources that was a limiter for the manufacturer to meet the customer requirements. This was also one of the top ten factors quoted by the Outsourcing institute (2006) in the literature review that led to outsourcing decision.

Two components of hypotheses were presented below. One was the positive impact to overcome the production and space limitation and the other was the positive impact to overcome the lack of technical content expert and support infrastructure internally.

Production and space limitation would be a limiter if capacity would be a constraint and space was limited for expansion. By outsourcing non-core function, this would create space and capacity flexibility for the companies to support the core business function or customers upside demand. Non-core business could be negotiated for lower cost by outsourcing to service providers if the bulk of the volume came from the outsourcer that could generate the service provider's revenue. This could be a win-win situation for both companies.

Outsourcing has positive impact to overcome production and space limitation if unavailable internally

Concern on lack of technical content expert in non-core or niche business segment could also be outsourced to seek best in class specialist for support. Likewise the unavailability of support infrastructure could also be solved by seeking external providers' solution.

Outsourcing has positive impact to overcome lack of technical content expert and support infrastructure if unavailable internally

\section{Outsourcing Decision}

The dependent variable of this research framework study would be the outsourcing decision which would be measured in terms of the consideration of outsourcing 
decision. As described in the ten hypotheses of independent variables, the factors that influenced outsourcing decision highly dependent on how customers perceive or consider the impact of outsourcing. The benefits of outsourcing varied from one company to another and the initiative to seek outsourcing strategy would also depend on the maturity of the companies in planning for strategic advantage and compete in the competitive market environment. According to Maurice F. Greaver II (1999) in the literature review, outsourcing decision would need a structured approach in planning and there would be associated risks of outsourcing if it was taken for granted according to Dean Davison (2006).

\section{RESEARCH METHODOLOGY}

A questionnaire was the principal instrument selected. As this was a quantitative and exploratory research, questionnaire would be used to collect data for the statistical research analysis. Data collected from the respondents would be processed into the SPSS (Statistical Package for Social Science) software to evaluate the factors or independent variables influencing outsourcing decision in manufacturing industry in Bangladesh. A preliminary research questionnaire was tested to ensure the correct formulation and understanding of the questions. A five-point scale was used as it was judged to be reasonable compromise between differentiation in the statistical analysis of data and making it easy for respondents to make a selection. Table 1 summarizes the measures used in the study questionnaire.

Table 1: Questionnaire Design

\begin{tabular}{|c|c|c|c|}
\hline Independent variables & Measurement Code & $\begin{array}{c}\text { No. of } \\
\text { Questions }\end{array}$ & Hypothesis \\
\hline Reduce operating cost & $\begin{array}{l}\text { Capital investment } \\
\text { Overhead \& fixed cost } \\
\text { Space }\end{array}$ & $\begin{array}{l}5 \\
5 \\
5\end{array}$ & $\begin{array}{l}\text { H1a } \\
\text { H1b } \\
\text { H1c }\end{array}$ \\
\hline Improve company focus & $\begin{array}{l}\text { Focus on new product development } \\
\text { Explore new market segment }\end{array}$ & $\begin{array}{l}5 \\
5 \\
5\end{array}$ & $\begin{array}{l}\mathrm{H} 2 \mathrm{a} \\
\mathrm{H} 2 \mathrm{~b} \\
\mathrm{H} 2 \mathrm{c}\end{array}$ \\
\hline $\begin{array}{l}\text { Access to world class } \\
\text { capibility }\end{array}$ & $\begin{array}{l}\text { Available of specialist } \\
\text { Latest and high efficiency technology } \\
\text { Established tool and support infrastructure }\end{array}$ & $\begin{array}{l}5 \\
5 \\
5\end{array}$ & $\begin{array}{l}\mathrm{H} 3 \mathrm{a} \\
\mathrm{H} 3 \mathrm{~b} \\
\mathrm{H} 3 \mathrm{c}\end{array}$ \\
\hline $\begin{array}{l}\text { Unavailablity of internal } \\
\text { resources }\end{array}$ & $\begin{array}{l}\text { Limited production capacity and space } \\
\text { Lack of content expert and support } \\
\text { Infrastructure }\end{array}$ & $\begin{array}{l}5 \\
5\end{array}$ & $\begin{array}{l}\mathrm{H} 4 \mathrm{a} \\
\mathrm{H} 4 \mathrm{~b} \\
\mathrm{H} 4 \mathrm{c}\end{array}$ \\
\hline Dependent Variable & Description of measurement & \multicolumn{2}{|c|}{ Number of questions } \\
\hline Outsourcing Decision & Outsourcing Decision & \multicolumn{2}{|c|}{10} \\
\hline
\end{tabular}

Questionnaire was adopted from Islam M.A. et al., (2006) 
The respondents targeted were the working adults from various manufacturing industry in Bangladesh. The purpose of this research was to assess the factors influencing outsourcing decision in manufacturing industry in Bangladesh. A total of 150 questionnaires were distributed to the selected working adults through non-probability convenience sampling approach. A total of 70 questionnaires were collected out of a 150 questionnaires that were distributed which made up of $46.67 \%$ response rate. This approach was selected due to its inexpensiveness and fast. The questionnaires were distributed through the social and working network of the researchers through personal contact and referrals.

\section{RESULTS}

\section{Respondents profile}

The majority respondents were male (53\%). Out of 70 respondents 40 were from the age group of 31-40 years old. Most of the respondents were from the management level in their occupation (60\%). 61.43\% companies have been in operation for about 5 to 10 years. 25 companies have 50 to 100 employees and only 8 companies in the sample have more than 500 employees. Table 2 presents the demographic profile of respondents.

Table 2: Demographic profile of respondents

\begin{tabular}{|c|c|c|c|}
\hline Factors & Categories & Frequency & Percentage \\
\hline \multirow[t]{2}{*}{ Gender } & Male & 55 & 75.71 \\
\hline & Female & 17 & 24.29 \\
\hline \multirow[t]{4}{*}{ Age } & $21-30$ & 11 & 15.71 \\
\hline & $31-40$ & 40 & 57.14 \\
\hline & $41-50$ & 11 & 15.71 \\
\hline & More than 50 Years old & 08 & 11.43 \\
\hline \multirow[t]{3}{*}{ Education } & Diploma & 03 & 4.23 \\
\hline & \begin{tabular}{|l} 
Degree \\
\end{tabular} & 23 & 32.86 \\
\hline & Masters and Others & 36 & 51.43 \\
\hline \multirow[t]{4}{*}{ Occupation } & Non Management & 04 & 5.71 \\
\hline & Executive & 20 & 28.57 \\
\hline & Management & 42 & 60.00 \\
\hline & Professional and others & 04 & 5.71 \\
\hline \multirow[t]{4}{*}{ Years of work experience } & Less than 5 years & 05 & 7.14 \\
\hline & $5-10$ years & 43 & 61.43 \\
\hline & $11-15$ years & 16 & 22.86 \\
\hline & More than 15 years & 06 & 8.57 \\
\hline \multirow{3}{*}{$\begin{array}{l}\text { Duration of Company established } \\
\text { (Years) }\end{array}$} & Less tjam 5 years & 17 & 24.29 \\
\hline & $5-10$ years & 43 & 61.43 \\
\hline & More than 10 years & 10 & 14.29 \\
\hline \multirow[t]{4}{*}{ No. of employees in the organization } & Less than 50 & 25 & 35.72 \\
\hline & $50-100$ & 25 & 35.72 \\
\hline & $101-500$ & 12 & 17.14 \\
\hline & More than 500 & 08 & 11.43 \\
\hline
\end{tabular}




\section{Goodness of data}

Reliability analysis was used to test the internal consistency and validity of the data gathered. Cronbach's alpha was chosen to analyze the degree of internal consistency among the items in a variable. Alpha coefficient ranges in value from 0 to 1 . The higher the score, the more reliable the generated scale is. Sekaran (2000) explained that reliability of a measure is established by testing for consistency and stability of data collected. All the variables, independents and dependent were tested to analyze its internal consistency. All of them showed an acceptable internal consistency, with Cronbach's alpha (á) ranging above 0.6 levels. Table 3 presents the results of the reliability analysis.

Table 3: Results of Reliability Analysis

\begin{tabular}{|l|c|c|c|}
\hline \multicolumn{1}{|c|}{ Variables } & Number of Items & Items Dropped & Cronbach Alpha \\
\hline Capital Investment & 5 & 1 & .657 \\
\hline Overhead and Fixed cost & 5 & 1 & .688 \\
\hline Space & 5 & 1 & .692 \\
\hline $\begin{array}{l}\text { Focus on New product Development and Explore } \\
\text { New Market Segment }\end{array}$ & 5 & - & .644 \\
\hline Availability of Specialist & 5 & - & .705 \\
\hline Latest Technology and High Efficiency & 5 & - & .674 \\
\hline Established Tool and Support Infrastructure & 5 & - & .699 \\
\hline Limited Production Capacity and Space & 5 & - & .686 \\
\hline $\begin{array}{l}\text { Lack of Technical Content Expert and Support } \\
\text { Infrastructure }\end{array}$ & 5 & - & .655 \\
\hline Outsourcing Decision & & & .720 \\
\hline
\end{tabular}

\section{Findings}

The Linear Regression Analysis was used to analyze the relationship between the dependent variable and the predictors or the independent variables. The key assumption is that the relationship between the dependent and the independent variables is linear. In this study, the dependent variable is the outsourcing decision and the predictors are capital investment, overhead and fixed cost, space, focus on new product development, availability of specialist, latest technology and high efficiency, established tools and support infrastructure, limited production capacity and space and lack of technical content expert and support infrastructure. The coefficient Table 4 below shows the results of the linear regression analysis. 
Table 4: Summary of Multiple Regression Results

\begin{tabular}{|l|r|r|r|}
\hline \multicolumn{1}{|c|}{ Factors } & Beta & T-Ratio & Sig. t \\
\hline Capital Investment & .150 & 1.865 & .86 \\
Overhead and fixed cost & .201 & 2.976 & .62 \\
Space & .224 & 1.985 & .52 \\
Focus on new product development & 5.734 & 7.971 & .000 \\
Availability of Specialist & -4.123 & -7.013 & .000 \\
Latest technology and high efficiency & -3.234 & -6.354 & .005 \\
Established tools and support infrastructure & -2.456 & -5.473 & .009 \\
Limited production capacity and space & .457 & 2.351 & .016 \\
Lack of technical content expert and support & 3.846 & 5.897 & .003 \\
\hline infrastructure R square $=66 \%$ & \\
\multicolumn{2}{|c|}{ Durbin Watson $=1.768$} \\
\hline
\end{tabular}

- Dependent variable: Outsourcing Decisions

From the results of the regression analysis, the $\mathrm{R}$ square of the model of this study is 0.66 . This indicates that approximately $66 \%$ of the outsourcing decision variability can be explained by this model. The Durbin-Watson variable of the model is 1.768 , indicating no auto-correlation problem in the data. The F statistics has an acceptable significant level of 0.000 , less than the 0.05 threshold, showing the variation explained by the model is not due to chance. Assessment on the co-linearity statistics shows the tolerance values for all the variables ranging from 0.005 to 0.815 . The VIF is also within the co-linearity range. Based on the SPSS output summarized in Table 2, all variables shown to have success at $5 \%$ significance level except capital investment, overhead and fixed cost and space variables.

\section{RECOMMENDATIONS}

Based on the key findings of this study, the result has shown that outsourcing had a positive effect on the variables of improve company focus, access to world class capability and solve the unavailability of internal resources. Before recommendations are offered, the researcher would like to recapitulate the objectives of carrying out the research study. The first objective of the study was to analyze what factors that were affecting the manufacturing operation industry in Bangladesh to run the operation in house. The researcher hoped to prove that outsourcing would be an alternative in reducing operation cost, improve company focus, access to world class capability and solve the problem of unavailability of internal resources. The second objective, the researcher hoped to relate the relationship on the factors affecting the manufacturing industry and the factors influencing the companies in considering outsourcing decision to outsource certain non-core business function areas and to determine how outsource could benefit 
the company in terms of lower operating cost, improve company focus, flexibility and efficiency in contributing to company revenues profitably.

With reference to the framework used in this study and data obtained from the results of the analysis, outsourcing decision has shown that all hypotheses were accepted except $\mathrm{H} 1 \mathrm{a}, \mathrm{H} 1 \mathrm{~b}$ and $\mathrm{H} 1 \mathrm{c}$ which respondents disagree on capital investment, overhead and fixed cost and space could be reduced by outsourcing. The rest of the hypotheses have shown positive results in meeting the researcher's two objectives. General recommendations are offered with generic guidelines for successful outsourcing management from its very beginning. The recommendations below also offer more indept guidelines for maximizing the benefits of outsourcing.

Recent high profile failures in outsourcing relationships have highlighted the need for companies to carefully assess their options and develop a sourcing strategy that ensures processes are handled where the work can best be done. However, this is easier said than done, especially in large organizations where many processes are interlinked or dependent on one another. In these instances, identifying and evaluating issues concerning what, how and where to outsource becomes increasing daunting. Most of the outsourcing selection is based on gut feel and cost reduction potential only, not taking into account other important parameters such as process linkages and criticality of the process. Companies need to evaluate their business processes and not only identify the right ones to outsource, but also the delivery model that will best support these processes. For instance, certain processes or business functions that involve high level of confidentiality could be outsourced to a joint venture center as opposed to a shared services or external vendor. It is recommended to any business function or process outsourcing initiative is to determine the following:

1. WHAT processes or business function can be outsourced?

2. WHEN these processes or business function should be outsourced? 3. WHERE can they be outsourced?

In many cases, the significant of frequent service management communication is overlooked. This is critical for partnership and service management. Communication needs to be carried out on a regular basis. Daily or weekly reports of service status based on a pre-set performance matrix should be available to the buyers as agreed per the service contract agreement. Weekly or monthly meeting is also crucial in keeping things intact for addressing both immediate concerns and long-term planning. Moreover, when there is a service needs or technological changes, buyers and the vendors should follow an established protocol to address it. The quality of communication also matters. The level of organizational involvement and the inclusion of relevant information are two main aspects. Communication should be done not only between low-level but also high- 
level managers when a major shift of focus is introduced. Service performance information should be kept in a shared drive or central depository and decision support modules should be in place for informed decision making.

Contract and service management is critical for the success of outsourcing projects. The service contract governs the relationship between the buyer and the external vendors. A poorly written contract is a recipe for disaster in most cases of outsourcing due to ambiguity and lots of gray areas. A sound contract other than standard terms and conditions, it should also include the provisions of regulation and policies of the project, performance measurement, cost structure, benchmarking, technological change, penalty for poor service and termination for convenience. Most of the service management concerns should be addressed when a service contract is negotiated to avoid any pitfalls in the future when disaster strikes. Six-Sigma application has been widely recognized globally. Most of the industry that applied this methodology, found it to be fruitful in achieving the objectives of the companies. This method is used to continually measure and improve performance and processes. It is a systematical framework to guide process improvement by DMAIC (Define, Measure, Analyze, Improve and Control). Inevitably, with a systematic approach, this would help in delivering faster project timelines, greater cost savings, reduced risks, increased work efficiency, constant work process improvement and greater situational awareness in outsourcing.

\section{CONCLUSION}

The researchers have explored the effect of reduce operating cost, improve company focus, access to world class capability and unavailability of internal resources as factors influencing outsourcing decision. The results showed significant effect and relationship towards outsourcing decision as an alternative. This study facilitated the identification of critical factors that contributing to outsourcing decision. From the survey, majority of the respondents agreed on the factors such as to reduce operational cost, improve company focus, gain access to world class capability and the unavailability of internal resources would lead to outsourcing. From the research, the objectives and research questions have met the researcher analysis and study. The research indicated only parts of the factors were studied even though ten top factors were identified based on the Outsourcing Institute literature review. The study has given some insight views and usefulness of the research data to the manufacturing industry in Bangladesh that are seeking way out due to the factors associated to their manufacturing limitations and affecting their profits. 


\section{REFERENCES}

Accounting Jobs (2005), Outsourcing Growth Seen for Finance. AccountingWEB.com May 27, 2005. http:/www.accountingweb.com/cgibin/item.cgi?id=100947

Bangladesh Economy, webpage available on March 28, 2008 at

http://www.euroitx.com/content/bangladesh_info_01.php

Bhagwati, Jagdish (1984), Splintering and Disembodiment of Senices and Developing Nations, World Economy, 7:2, pp. 133-44.

Bhagwati, Jagdish et al (2004) The Muddles over Outsourcing, The Journal of Economic Perspectives, Vol. 18, No. 4. (Autumn, 2004), pp. 93-114.

Cook, Mary F. and Gildner, Scott B. (2008) Outsourcing Human Resources Functions found available on March 4, 2008 at http://www.shrm.org/books/outsourcinghr2/excerpt.asp

Cynthia A. Kroll (2004), Background on Business Services Outsourcing Testimony. Haas School Business, University of California Berkeley, March 92004

Dr. Albert SantaLuca and Dr. Philip McCready (2006), Opportunities and Threats of Business Process Outsourcing: Trends for South Metro Denver. Innovation Economics LLC, June 13th 2006.

Dean Davison (2006), Top Ten Risks of Offshore Outsourcing. Meta Group Inc. Analyst Corner, 2006

David Mackey and Kaye Thorne (2003), Everything You Ever Needed To Know About Training, 3 edition, 2003

Don Brown (2002), Government Outsourcing: Making the Decision. CSC World. Dec 2002 - Feb 2003.

Dr. Wendell Jones (2001), Planning for an Outsourcing Evaluation: The First Phase. Outsourcing Center, March 2001

El'millian Chew Saint Fey (2005), Business Process Outsourcing. Penang Economic Monthly, Volume 7, Issue 7, July 2005 
Feenstra, Robert C. (1998), Integration of Trade and Disintegration of Production in the Global Economy, Journal of Economic Perspectuves, Vol. 12 (4), pp. $31-50$

Frederick G Hillmer (1995), Strategic Outsourcing, The McKinsey Quarterly, No.1, 1995

Frank J Casale (2006), Outsourcing Essentials, The Outsourcing Institute, Vol 3. No. 6 Summer 2006.

http://www.outsourcing.com/content.asp?page=01b/other/oe/q605/default.ht ml\&nonav $=$ false

Hsieh, Chang T. and Woo, Keong T. (2005), The Impact of Outsourcing to China on Hong Kong's Labor Market, The American Economic Review, Vol. 95, No. 5. (Dec., 2005), pp. 1673-1687.

Huff, S (1991), Outsourcing of Information Services, Business Quarterly, pp6265, Spring 1991

Source: http://www.marketresearch.com/browse.asp?categoryid=1623

Hummels, David et al. (2003), The Nature of Growth of Vertical Specializaton in World Trade, Journal of International Economics, Vol. 54 (1), pp. 75-96

Info-Tech White Papers (2003), How to Optimize Outsourcing Relationship. Info-Tech Research Group, 2003.

Info-Tech Research Group (2003), How to Optimize Outsourcing Relationships.

Janet Whitman (2001), Strategic Deals are the most likely to Fail, Study Says. Wall Street Journal, August 7th, 2001

Jane C. Linder (2004), Outsourcing for Radical Change: A Bold Approach to Enterprise Transformation. AMACOM 2004.

Judith Hale (2005), Outsourcing Training and Development: Factors for Success. Pfeiffer, Dec. 2005

J.P. Frenza (1999), Buying Web Services the Survival Guide to Outsourcing. New York: Wiley, 1999 
Jonathan Reuvid and John Hinks (2001), Managing Business Support Services: Strategies for Outsourcing and Facilities Management, Second Edition. Kogan Page 2001

Lynch, Clifford F (2000), Supply Chain Management Review. Managing the Outsourcing Relationship, 2000

Maurice F. Greaver II (1999), Strategic Outsourcing: A Structured Approach to Outsourcing Decisions and Initiatives. Amacom 1999

Malhotra, Naresh K (2002), Basic Marketing Research: Applications to Contemporary Issues. International Edition, Prentice Hall, 2002.

Manage HR Functions Successfully, available on March 04, 2008 at http://www.shrm.org/books/outsourcinghr2/default.asp\#toc

Mandhavi Mantha (2005), BPO in Banking: A Review of Strategies and Trends. Celent, May 26th 2005.

Md. Aminul Islam, and Teoh T.J., (2007). "The factors that are affecting the outsourcing decision in the Manufacturing Industry in Penang". Presented in the 7th International conference organized by the Asian Academy of Management, Penang, Malaysia. May 2007.

Paul Gustafson (2002), Emerging Technologies in Business. CSC World. Dec 2002 - Feb 2003.

Richard G Weissmann (2005), Global Outsourcing Planning Process/Steps. Northeast Supply Chain Conference, 2005.

Robert C Feenstra and Gordon H Hansen (2006), Ownership and Control in Outsourcing to China. The Quarterly Journal of Economics, Vol 120, No.2 May 2005

Saunders, C.,Gebelt,M. and Hu Q. (1997), Achieving Success in Information Systems Outsourcing. California Management Review, pp.63-79, Winter 1997

Small Business IT Outsourcing White Paper (2002), Outsourcing Advantages. Progent Corporation, 2002. http://www.progent.com/pdf/outsource.pdf Socio-economic and Environmental Research Institute; http://www.seri.com.my 
Sandra Ward (2004), Outsourcing Research: What is your position?. Business Information Review. Vol. 21. SAGE Publication 2004.

The Outsourcing Institute (2006), Executive Survey: The Outsourcing Institute's Annual Survey of Outsourcing End Users http://www.outsourcing.com/content.asp?page $=01 \mathrm{~b} /$ articles/intelligence/oi top_ten_survey.html\&nonav=true

TechWeb Technology News (2004), Offshore Outsourcing Growth is Expected to Continue Unabated. The Business Technology Network, Oct 12, 2004

The Benefits of Outsourcing for Small Businesses. http://www.allbusiness.com/human-resources/workforce-managementhiring/1084-1.html

Uddin, Gazi M. (2005) The Challenges and Prospects of Effective HR Outsourcing for Managerial Activities in the Corporate World of Bangladesh, AIUB Journal of Business and Economics, Volume 4, pp. 91-104

V. Krishna Polineni.(2001), The 3R's of Offshore Outsourcing. Serebrum Corporation, 2001

William C. Evans (2002), Successful Integration: Fundamental to Outsourcing Success. CSC World. Dec 2002 - Feb 2003

Source:http://www.csc.com/aboutus/cscworld/december02/CSCWorld_DecF eb03.pdf

Zeile, William J. and Hanson G. (2003), US Intrafirm Trade in Goods, Survey of Current Business, Vol. 77 (2), pp. 23-38

The ideal with which you go forth to measure things determines the nature, so far as you are concerned, of everything you meet.

- H.W. Beecher 
https://ir.iba.edu.pk/businessreview/vol5/iss2/8

DOI: https://doi.org/10.54784/1990-6587.1248

Business Review - Volume 5 Number 2

July - December 2010

A successful society is characterized by a rising living standard for its population, increasing investment in factories and basic infrastructure, and the generation of additional surplus, which is invested in generating new discoveries in science and technology.

- Robert Trout 